\title{
LENGUA X: AN ANDEAN PUZZLE ${ }^{1}$
}

\author{
Matthias Pache
}

LEIDEN UNIVERSITY

\begin{abstract}
In the south-central Andes, several researchers have documented series of numerical terms that some have attributed to a hitherto unknown language: Lengua $\mathrm{X}$. Indeed, they are difficult to link, as a whole, with numerical series from the known languages of the area. This paper discusses the available information on these series and attempts to trace their origin. It is difficult to argue that they are the remnants of a single, vanished language. Instead, it is argued that Lengua X numbers for 'one' and 'two' originate in Aymara, a language from the highlands, whereas terms for 'three' to 'five' originate in Mosetén, a language from the eastern foothills. Additional parallels with Uru-Chipayan, Quechua, and Aymara (terms from 'six' to 'ten') suggest that Lengua $\mathrm{X}$ numbers reflect a unique and complex situation of language contact in the south-central Andes.
\end{abstract}

[Keywords: Lengua X, Aymara, Mosetén, Uru-Chipayan, numbers, language contact]

1. Introduction. Since the colonial period, four indigenous language groups have been associated with the south-central Andes: Quechua, Aymara, Uru-Chipayan, and Puquina (e.g., Bouysse-Cassagne 1975; Adelaar 2004). Since the late nineteenth century, however, several researchers (e.g., Posnansky 1938; Vellard 1967) have come across words in the Bolivian highlands for numbers that seem to belong to a different language: Lengua X, as it was called by Ibarra Grasso $(1982: 15,97)$. This paper presents and discusses Lengua $X$ numerical terms, addressing the question of their origin.

Table 1 illustrates the first four numbers of Lengua X, together with their counterparts in Aymara, Chipaya (Uru-Chipayan), Bolivian Quechua, and Puquina. ${ }^{2}$ The Lengua $\mathrm{X}$ numbers $<$ mayti> 'one' and <payti> 'two' are clearly

\footnotetext{
${ }^{1}$ The research for this paper was funded by the European Research Council under the European Union's Seventh Framework Programme (FP7/2007-2013) / ERC Grant Agreement No. 295918. The author's fieldwork in Irohito, carried out from 20 July to 21 August 2011, was funded by the DAAD (Deutscher Akademischer Austauschdienst). I wish to thank Ciriaco Inda Colque and Rosendo Inda Inda from Irohito, who contributed to this paper with information on Lengua X numbers, and the community of Irohito for its support during my research stay. I am grateful to Willem Adelaar, David Beck, Nick Emlen, Harald Hammarström, Katja Hannß, Bruce Mannheim, Matthias Urban, Jupp Zenzen, and to three anonymous reviewers for their valuable comments on the manuscript, and to Arjan Mossel for creating a map.

${ }^{2}$ The transcriptions of indigenous language data that are not given between chevrons are phonemic and mostly follow the respective sources.

[IJAL, vol. 84, no. 2, April 2018, pp. 265-85]

(C) 2018 by The University of Chicago. All rights reserved.

0020-7071/2017/8304-0004\$10.00 DOI 10.1086/696199
} 
TABLE 1

Numbers from 'One' to 'Four' in Several Languages of the South-central Andes

\begin{tabular}{llllll}
\hline \hline & \multicolumn{5}{c}{ Language } \\
\cline { 2 - 6 } Number & Lengua X & Aymara & Chipaya & Bolivian Quechua & \multicolumn{1}{c}{ Puquina } \\
\hline 1 & $<$ mayti> & maya & $t^{h} i:$ & huk & $<$ hucsto $>,<$ pesc $>$ \\
2 & $<$ payti $>$ & paya & pişk & iskay & $<$ so $>$ \\
3 & $<$ iriti> & kimsa & $\check{c}^{h}$ ep & kimsa & $<$ cap(p)a $>$ \\
4 & $<$ yuncati> & pusi & paqpik & tawa & $<$ sper $>$ \\
\hline
\end{tabular}

Data from Ibarra Grasso (1982:98), Adelaar (2004:294-95), Rosat Pontacti (2004), Cerrón-Palomino (2006:105). A fuller account of numbers in Andean languages is given in table I in the appendix.

related to Aymara maya 'one' and paya 'two'. Otherwise, Lengua X terms widely differ from numbers in Andean languages illustrated in table 1.

2 will introduce and discuss the data available on Lengua $X$ numbers from a synchronic perspective. $\mathbf{3}$ will discuss them from a diachronic perspective, broaching the issue of possible external relations. Finally, $\mathbf{4}$ summarizes the observations made in this paper and discusses their implications.

2. Lengua $X$ : The data. The only data from Lengua $X$ are the numbers 'one' to 'ten'. The most detailed account of these terms is given by Ibarra Grasso (1982) in Las lenguas indígenas de Bolivia (an extended version of Ibarra Grasso 1964). The terms in question have not received much attention in the scientific literature, though they have been mentioned-only relatively recently, as stressed by Ibarra Grasso (1982:97), and under different labels_-by scholars such as Bandelier (see Wrigley 1917:194), Posnansky (1938:53), or Vellard (1967:36).

As illustrated in figure 1, Lengua $\mathrm{X}$ numbers have been recorded in an area extending for several hundred kilometers along a northwest-southeast axis. The area's east-west extension appears to be relatively narrow. At present, it is populated mostly by people speaking Aymara. Also, the geographic distribution of Lengua X terms roughly coincides with the distribution of groups categorized, since the sixteenth century, as "Uru" by the Spaniards, and with the diffusion of Uru-Chipayan languages until the mid-twentieth century (cf. Vellard 1954; Montaño Aragón 1972; Bouysse-Cassagne 1975; Wachtel 1978).

The different Lengua $\mathrm{X}$ series attested in the literature and gathered during the author's fieldwork in Irohito (Ingavi Province, La Paz Department, Bolivia) are illustrated in table 2 . None of the sources has evidence suggesting that Lengua $X$ terms were the only words for numbers used by any of the consultants. The language habitually spoken by the consultant, when known, is indicated in a footnote. ${ }^{3}$ The terms that are underlined in table 2 will be linked, in $\mathbf{3}$, with corresponding elements from other languages.

\footnotetext{
${ }^{3}$ As to elicitation of these series by the author in Irohito, the consultants Ciriaco Inda and Rosendo Inda were asked in separate, individual sessions about numerical series that they knew
} 


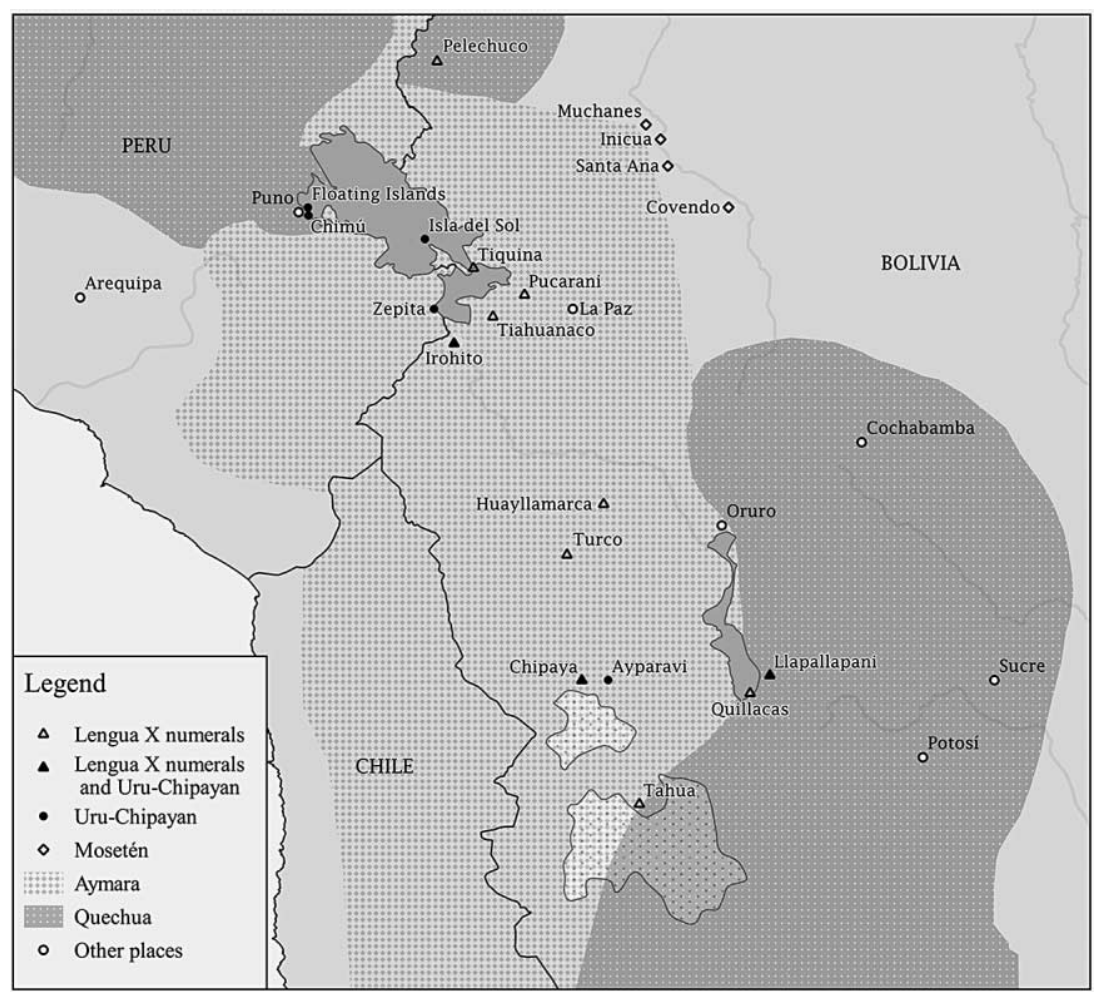

FIG. 1-Twentieth-century distribution of indigenous languages discussed in this paper. Places where Lengua $X$ words were recorded are indicated with triangles. The map was created by Arjan Mossel, based on data from Ibarra Grasso (1982), Grimes (2000), Adelaar (2004), and Sakel (2004).

As can be seen in table 2, Lengua $X$ numerical series are not consistent across the different places indicated in figure 1 . This is particularly true among higher numbers: for 'nine', for instance, the forms $<$ ačíči $>,<$ aran $>,<$ chaleco $>$, $<$ chareta $>$, <chinini $>$, $<$ chipana $>,<$ kolke $>$, and $<$ taksum $>$ were recorded in different places. Also, some Lengua $\mathrm{X}$ words given in table 2 are attested only once, such as <acargu> 'six' from Llapallapani (Sebastián Pagador Province, Oruro Department, Bolivia) (Ibarra Grasso 1982:106). Regardless of these

in Aymara, Uchumataqu (the Uru-Chipayan language formerly spoken in Irohito), and any other words for numbers they knew. Both consultants were 43 years old at the time of the recording. In everyday communication within the community, both use Aymara. During elicitation, the language of interaction was Spanish. No specific stimuli were used and no "give a number" tasks were undertaken. The inclusion of Ciriaco Inda and Rosendo Inda was based on their willingness to collaborate and on their knowledge of the words in question. 


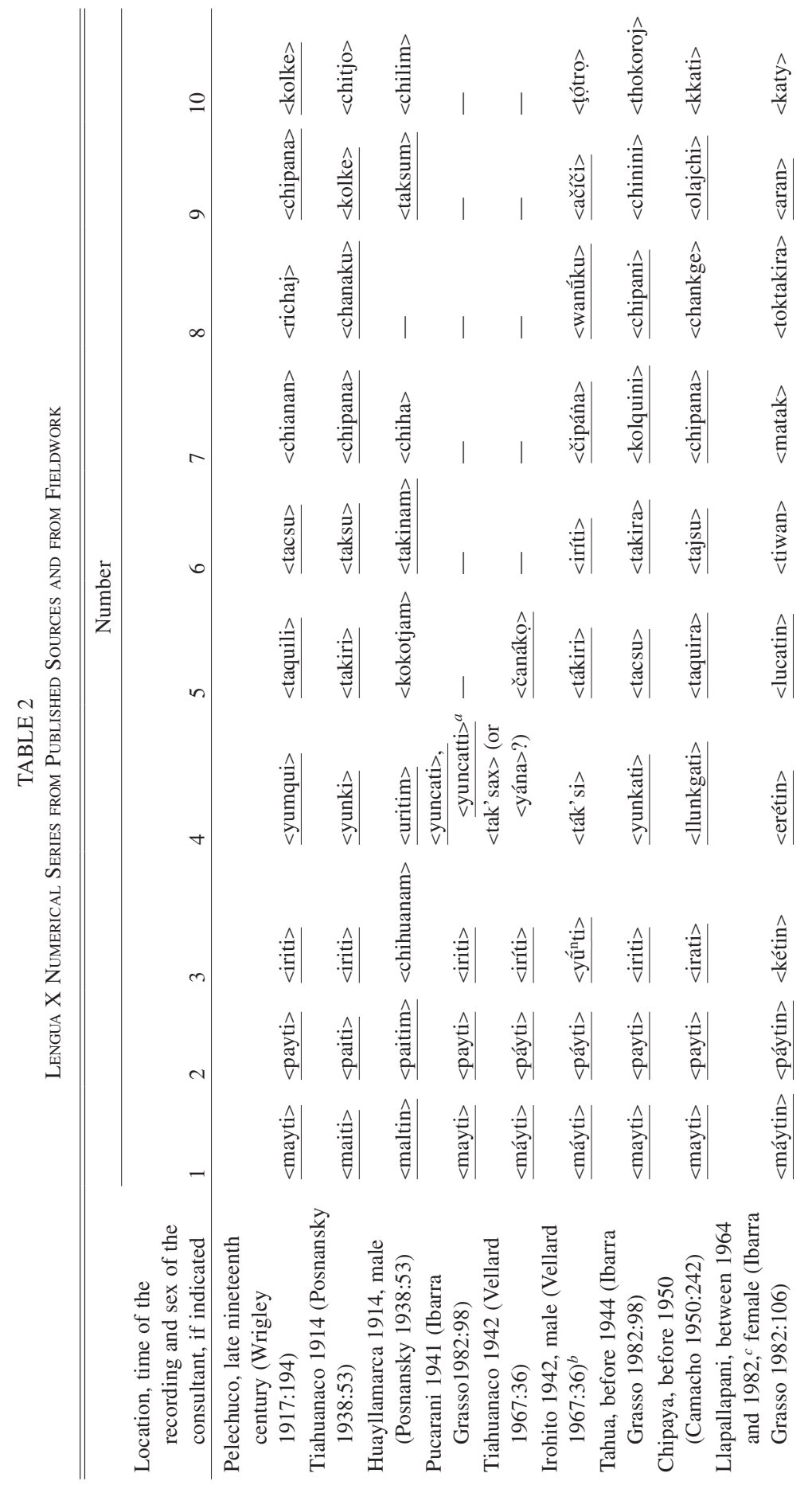




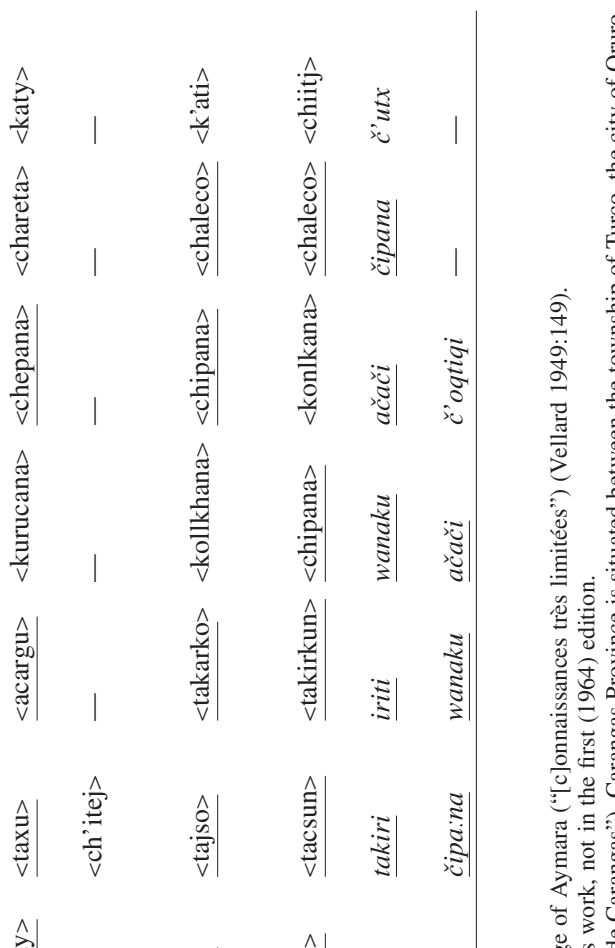



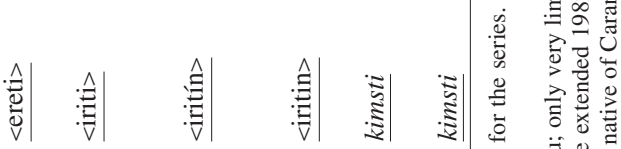





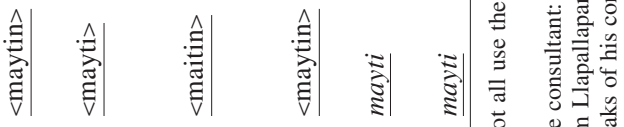

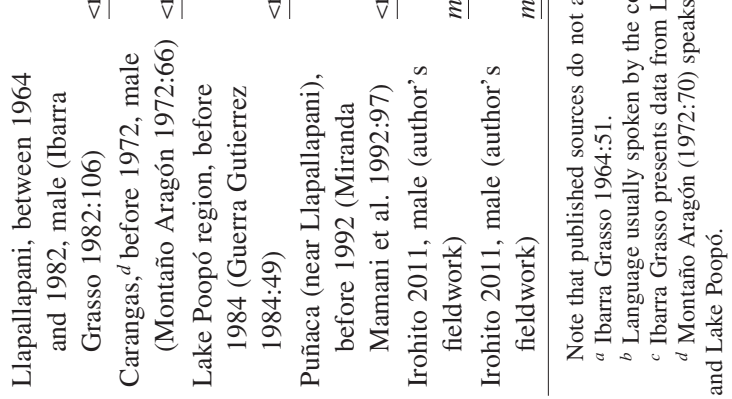


inconsistencies, the terms in table 2 have been tentatively attributed to Lengua $X$ as a single language by Ibarra Grasso (1982) and Montaño Aragón (1972). Even among the Lengua $\mathrm{X}$ numbers recorded in a single community, differences can be observed. This was mentioned by Ibarra Grasso (1982:106) in the context of the two series recorded in Llapallapani from a male and female speaker, given in table 2. Another case of variation between two consultants from the same community is attested in the two Lengua $\mathrm{X}$ series recorded in Irohito by the author, also given in table 2. Instead, a relative stability or coherence of certain Lengua $X$ terms is reflected by the fact that some of them, especially smaller numbers, are regularly attested across different consultants and places. This is illustrated in figure 2 , which shows the frequencies of several Lengua $\mathrm{X}$ numbers listed in table 2.

In addition to being the most widespread Lengua $\mathrm{X}$ terms, $<$ mayti> 'one', $<$ payti> 'two', <iriti> 'three', and <yunkati> 'four' also exhibit the most coherence and stability with respect to form and meaning (figure 2; see also Pica et al. 2004:501). This may also indicate that at the time of recording, Lengua $X$ numbers were no longer used as a regular counting device-if they ever were-in the south-central Andes. This would be consistent with an observation made to me by Ciriaco Inda in Irohito: Lengua $X$ terms are not in everyday use, but they are occasionally still taught to children in some families. Ibarra Grasso (1982:98) mentions a market woman from Pucarani (Los Andes Province, La Paz Department, Bolivia) who told him, during a fieldwork trip in 1941, that she had learned these words for numbers from her clients. Little has been said in the literature about the use of Lengua X terms today. An exemplary function of Lengua $X$ numbers has been proposed by Ibarra Grasso (1982:102); he observes, in two instances, that Lengua X words for numbers are used among pupils in order to communicate without being understood by others. ${ }^{4}$

3. Lengua $\mathbf{X}$ numbers: Possible origins. The differences between Lengua $\mathrm{X}$ numbers and those in other Andean languages raise questions about their origin (see table 1, and table I in the appendix). Ciriaco Inda from Irohito, for instance, suggests that Lengua $X$ terms were brought by itinerant Kallawaya healers visiting from the eastern lowlands. ${ }^{5}$ Kallawaya is a secret language that draws part of its lexicon from the extinct Puquina

\footnotetext{
${ }^{4}$ Similarly, ancient or foreign words might be preserved in children's counting rhymes across different parts of the world: compare, for instance, English eeny, meeny, miny, moe, which might be related to Celtic numbers (Opie and Opie 1997:156-58), or a French counting rhyme beginning am, stram, gram, which might reflect German eins, zwei, drei 'one, two, three' (Ifrah 1994:518).

${ }^{5}$ Ciriaco Inda quotes his great-uncle Manuel Inta in this context, stating that Kallawaya healers trading medicine frequently came to Irohito; they were accommodated in the inhabitants' houses. Note that Manuel Inta, mentioned here, is not the same as Vellard's main consultant, also named Manuel Inta, who lived from 1865 to 1948 (cf. Muysken 2010:101).
} 


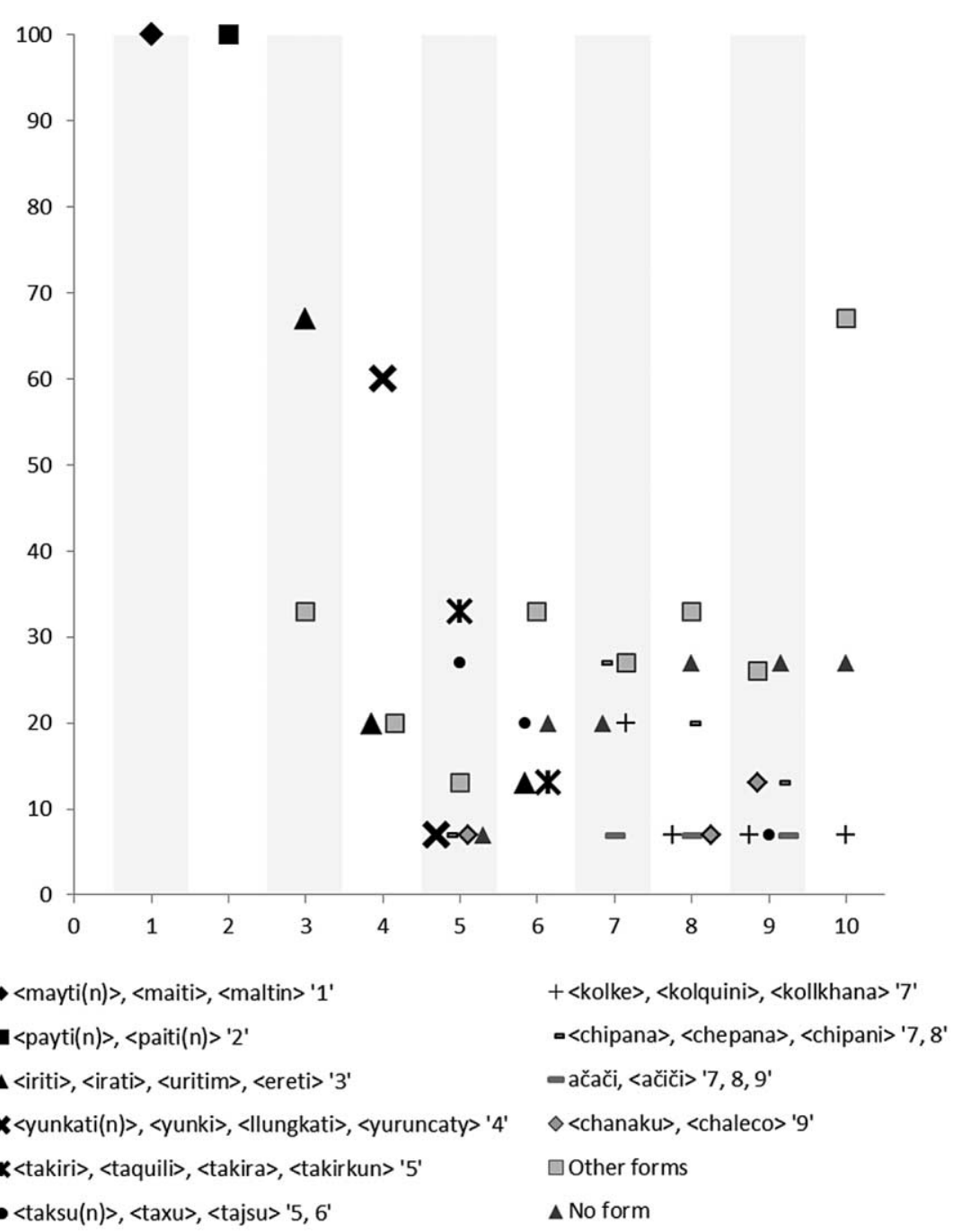

FIG. 2-Frequencies of some Lengua X numerical terms from table 2, with associated values. In the legend, only the most frequently attested forms and meanings are given. The $x$ axis indicates number; the $y$ axis indicates the response frequency in percentages.

language (e.g., Hannß 2014a). A Kallawaya origin is also postulated by the Swiss anthropologist Bandelier (Wrigley 1917:194) for the words he recorded in the late nineteenth century in Pelechuco (Franz Tamayo Province, La Paz Department, Bolivia) (see table 2). However, there seem to be few connections between Kallawaya and Lengua X, as Montaño Aragón 
(1972:66) points out. (For the Kallawaya terms, see table II in the appendix.) Other inhabitants of Irohito explain the origin of the numbers differently, stating that they came to the community with wood traders from the lowlands (Achim Schumacher, personal communication, September 2015). Posnansky (1938:53) claims that the terms he recorded in Huayllamarca in 1914 (Nor Carangas Province, Oruro Department, Bolivia, cf. table 2) have an Arawakan origin. ${ }^{6}$ A link between Lengua X numbers and Arawakan languages is refuted by Ibarra Grasso (1982:98). (For numbers in Apolista, one of the geographically closest Arawakan languages, see table II in the appendix.) Since the identification of putative vestigial "Aruwak" elements among the populations of the Andes is the leitmotiv of Posnansky's book, his position (1938:19) might in fact not be so far from Vellard's (1967:36), who refers to the series in question as "old number words from the Titicaca region." 7 Finally, Ibarra Grasso $(1982: 97,102,104)$ suggests that the words may belong to a specific but unknown language which might eventually turn out to be still spoken somewhere: Lengua $\mathrm{X}$. This suggestion is based on ethnohistorical sources mentioning unidentified languages formerly spoken in the south-central Andes, and on obscure toponyms in the area that cannot be linked to any known language. However, Ibarra Grasso does not draw any definite conclusions about Lengua $\mathrm{X}$ being an independent language from this kind of evidence. Montaño Aragón (1972), quoting Ibarra Grasso's (1964) hypothesis, tentatively connects Lengua X words with an Andean population he refers to as the Capillu or Q'oro, living near Turco (Sajama Province, Oruro Department, Bolivia; figure 1) in two townships: Yarbichambi and Rosapata. He refers to their language as Champirillu. Montaño Aragón (1972:67-69) argues that Ibarra Grasso's Lengua X might be Champirillu, for three reasons: (1) Champirillu is distinct from Aymara, according to his consultants; (2) some toponyms in western Oruro do not appear to be Aymara or Chipaya; and (3) Champirillu is spoken in an area where Lengua $\mathrm{X}$ numbers are attested. He does not provide more linguistic evidence in support of the suggestion that Lengua $\mathrm{X}$ is Champirillu, nor is any evidence for such a hypothesis supplied by Guerra Gutiérrez (1984:5053), who also provides firsthand observations on the Capillu. Another possible candidate for an extinct Andean language as a source of Lengua $\mathrm{X}$ numbers would be Chholo, formerly spoken near Llapallapani, according to one language consultant in Puñaca (figure 1) (Schumacher et al. 2009). Miranda Mamani et al. (1992:97) state that the Chholo numbers are as follows: $<$ maytin>, < paytin>, <iritin>, <yunkatin>, <tacsun>, <takirkun>, <chipana>, $<$ konlkana $>,<$ chaleco $>,<\operatorname{chiitj}>$ (see table 2). I agree with Schumacher et

\footnotetext{
${ }^{6}$ In an idiosyncratic interpretation, by the term "Aruwak" Posnansky does not refer to Arawakan as a language family but as a racial concept (1938:148).

7 "Numeración antigua de la región del Titicaca" (Vellard 1967:36).
} 
al. (2009:122), who do not see any reason to argue that Lengua $X$ numbers are genuine Chholo forms, given the fact that they are so widely attested in the south-central Andes. ${ }^{8}$ The same objection also holds for an exclusive link between Lengua $\mathrm{X}$ numbers and the unknown Champirillu language of the Capillu.

In the following three subsections, I illustrate the Lengua $\mathrm{X}$ numbers and their parallels in nearby indigenous languages. 3.1 discusses the Lengua $X$ words for 'one' and 'two'. $\mathbf{3 . 2}$ discusses the terms for 'three' to 'five', and 3.3 discusses Lengua X numbers from 'six' to 'ten'.

3.1. 'One' and 'two': An Aymara origin. The first Lengua X numbers, mayti 'one' and payti 'two', strongly resemble their counterparts in Aymara, namely mayni (used for humans), maya ma: (default) 'one', and pani, panini (humans), paya pa: (default) ‘two' (De Lucca 1983:660, 88283). These parallels between Lengua $X$ and Aymara have been observed by several researchers (e.g., Wrigley 1917; Camacho 1950; Montaño Aragón 1972; Ibarra Grasso 1982). The Aymara numbers maya and paya also have cognates in Jaqaru, an Aymaran language from central Peru: mayni (used for humans), maya (animals and objects) 'one' and pani (humans), paxa (animals and objects) 'two' (Belleza Castro 1995). Based on these forms, Cerrón-Palomino (2000:364) reconstructs the Proto-Aymaran forms *maya and *paya. The element $-t i$, as found in Lengua $\mathrm{X}$ mayti and payti, will be explained in the next subsection.

3.2. 'Three' to 'five': A Mosetén origin. The Lengua $X$ words for numbers from 'three' to 'five' seem to originate in Mosetén, one of two closely related languages/dialects spoken east of the Bolivian Andes (Beni and La Paz Departments) (Adelaar 2004:618; figure 1). The link between Lengua X numbers and Mosetenan is not immediately apparent in the terms attested in the modern languages - compare Mosetén hiri 'one', pãrõ? 'two', $\check{c}^{h}$ ibin 'three', ciis 'four' (Sakel 2004:167; for more Mosetenan numbers see table II in the appendix). However, the connection becomes clearer when a peculiarity of counting systems in many lowland South American languages is taken into account. Across different languages from northwestern Amazonia, the word for 'three' derives from the expression 'alone' or 'without a sibling/brother'. This is the case, for instance, in Kakua (Kakua-Nukak) (Bolaños 2016:229), Murui (Witotoan) (Wojtylak 2015), Hup (Nadahup) (Pozzobon 1997:167; Epps 2006:268), and Dâw (Nadahup)—in the latter

\footnotetext{
8 "Estos números no se pueden relacionar claramente con la familia lingüística uru-chipaya, ni tampoco son una particularidad de la lengua de los uru-muratos. Más bien constituyen un fenómeno con una gran extensión geográfica en el altiplano" (Schumacher et al. 2009:122). During the fieldwork of Schumacher et al., the consultant Daniel Moricio did not remember the Chholo words for these numbers.
} 
language it refers to odd numbers (five, seven, nine) in general (Martins and Martins 1999:265). Also, among the Bakairí, a Carib-speaking group of the Brazilian Mato Grosso, Steinen's consultants, when confronted with random groups of three maize kernels, always arranged them into one pair and one single kernel (Steinen 1894:408). When this evidence from other South American groups is considered, it seems possible to compare Lengua $\mathrm{X}<$ iriti> 'three' with Mosetén hiri-ty'i? 'alone (masculine)' (cf. Sakel 2004:172). This Mosetén form is derived from hiri 'one'. The final $-t^{y} i$ i is a nominalizing element, indicating masculine gender, according to Sakel (2004:96-99). In Chimane, the sister language/dialect of Mosetén, the corresponding forms are yiri? 'one time' and yiri-tyi-s 'one' (Gill 1999:110).

A term for 'three' based on expressions such as 'alone' or 'without a sibling/brother' is consistent with several instances in lowland South American languages in which numbers for 'four' mean something like 'having a brother/sibling/friend' (cf. Epps 2006:268; Epps et al. 2012:68). This kind of construction for 'four' was observed as early as the seventeenth century in Guaraní (Montoya 1639:178v) and has since been recorded in many apparently unrelated languages of lowland South America, including Hup (Martins and Martins 1999:265; Epps 2006:265), Murui (Wojtylak 2015), Tariana (Arawakan) (Aikhenvald 2002:108), Trumai (isolate) (Guirardello 1999:47), and Tucanoan languages (Pozzobon 1997:169). Also, the Chimane term for 'four', wãhped $e$ ?, appears to contain the elements wã h 'together' and ped $e$ ? 'friend' (cf. Gill 1999:110) and is built on the same model. ${ }^{9}$ In other cases, the word for 'four' derives from the term for 'other', as in Parintintin, a Tupí-Guaraní language (Schleicher 1998:13). Schleicher asserts that "[t]he overall picture for P[roto-]T[upí-]G[uaraní] is a language which in truth had no number words per se; instead of 'one', 'two', 'three', 'four', one would more correctly gloss these as 'that', 'pair/couple', 'few', and 'another'" (1998:13; emphasis added). A similar situation has been observed by Lehmann (1920:527) in the Miskito language of northeastern Nicaragua and eastern Honduras, which belongs to the Misumalpan family. The Miskito term <ŭâla> 'other' recurs in the words for 'two' <ŭal> (Lehmann 1920:527) and 'four' <ŭăl-ŭăl> (1920:526). In consequence, Lengua $\mathrm{X}<$ yunkati $>$ and related forms for 'four' may be compared with Mosetén yok-ty $i$ ' '(an)other (masculine)' (cf. Sakel 2004:87, 112). In Gill's (1999) Chimane data, I could find no counterpart of this form.

The nominalizing element $<\mathrm{t} i>-t^{y} i$, attested in Lengua $\mathrm{X}<\mathrm{iriti}>/$ Mosetén hiri-ty $t^{y}$ ? and Lengua $\mathrm{X}<\mathrm{yunkati}>/$ Mosetén yok-ty $i$, may have spread via analogy to Lengua X mayti 'one' and payti 'two' (see 3.1).

\footnotetext{
${ }^{9}$ An anonymous reviewer observes that terms for 'four' with the meaning '(having a) brother/ sibling/friend' are also found outside of the area in which the term for 'three' derives from 'without a sibling/brother' or 'alone'.
} 
Finally, Lengua $\mathrm{X}<$ takiri> 'five' might be linked with Mosetén $t^{y} a k$ 'ten' and hiri 'one' (cf. Sakel 2004:167). The corresponding form in Chimane is yiri?tak or -tak 'ten' (Gill 1999:110). It seems possible to compare the term for 'ten' in Mosetenan with the term for 'five' in Lengua X for the following reason: Pairs as counting units seem to be a widespread phenomenon in South American languages, and numbers that are connected across different languages (such as Mosetenan $t a k / t^{y} a k$ 'ten' and Lengua $\mathrm{X}<$ takiri $>$ 'five') may indicate the number of pairs in one language and the number of single items in the other. As can be gleaned from table I in the appendix, this also seems to be the case in the context of Puquina <pesc> 'one' and Uchumataqu (Uru from Irohito) piski ‘two’ (cf. Cerrón-Palomino and Ballón Aguirre 2011:18), or in Aymara pusi 'four' and Quechua pusaq 'eight'. ${ }^{10}$ Thus, whereas Puquina $<$ pesc $>$ 'one', Aymara pusi 'four', and Lengua $\mathrm{X}<$ takiri> 'five' are used to count single units, their counterparts in Uchumataqu (piski 'two'), Quechua (pusaq 'eight'), and Mosetenan (tak/t'ak 'ten') seem to have originally referred to pairs. ${ }^{11}$ Similar counting patterns are also found in other parts of the world, as an anonymous reviewer points out. For instance, in Mangareva (a Polynesian language from the Gambier Islands of French Polynesia) number terms do not necessarily refer to quantities of single items. In the context of culturally salient or valued entities, they may refer to counting units whose size depends on what specifically is being counted. If turtles are counted, the counting unit is one, whereas it is two in the case of fish being counted (Bender and Beller 2014:1324).

Since the parallels of Lengua X numbers concern morphologically complex forms in Mosetén, the latter must be considered to be the donor. The parallels that could be uncovered in Chimane are less obviously related to Lengua X terms. Table 3 summarizes the similarities between Lengua $\mathrm{X}$ and Mosetén forms.

3.3. 'Six' to 'ten': Parallels with Uru-Chipayan and other languages. As for the external relations of the Lengua $X$ words for 'six' to 'ten', it is more difficult to provide a simple explanation; not only do speakers frequently disagree about what the higher numbers are (see table 2 and figure 2), but the connections between Lengua $X$ and other languages do not always suggest an obvious origin.

${ }^{10}$ I am grateful to Willem Adelaar for pointing out the possible relationship between the Quechua and Aymara forms.

${ }^{11}$ Note also Lengua $\mathrm{X}$ iriti, which regularly refers to 'three' but indicates 'six' according to two consultants from Irohito (see table 2). Among lowland South American peoples, counting gestures are based on pairs in several cases: among the Carib-speaking Bakairí of southwestern Brazil (Steinen 1894:406-7); among two Chibchan-speaking groups, namely the Ette (Chimila) of northern Colombia (Niño Vargas 2009) and the Barí of eastern Colombia and western Venezuela (my own fieldwork data); and among the Kakua of the Colombian-Brazilian border region (Bolaños 2016:228-30). 
TABLE 3

Parallels between Lengua X Numbers and MosetéN

\begin{tabular}{ll}
\hline \hline Mosetén & Lengua X \\
\hline$-t^{y} i$ ? nominalizing element & $<$ mayti> 'one', <payti> 'two' \\
hiri-ty' $i$ ' 'alone (masculine)' & $<$ iriti> 'three' \\
yok-t $t^{y} i$ ' 'another (masculine)' & $<$ yunkati>, <yunki> 'four' \\
$t^{y} a k$ 'ten', hiri 'one' & $<$ takiri> 'five' \\
\hline
\end{tabular}

Additional Lengua $\mathrm{X}$ items might be related to Mosetenan. For instance, Lengua $\mathrm{X}<$ aran $>$ 'nine' in table 2 might be compared with Mosetén arah-ty $a k$ 'nine' (cf. Sakel 2004:167) and Chimane arah-tak (= "almost-ten") (cf. Gill 1999:110). The Mosetenan terms are probably calqued from Southern Aymara $<$ llalla tunca $>$ (= "almost-ten") (Bertonio 2006 [1612]:317), or vice versa.

TABLE 4

Parallels between Lengua $X$ and Uru Numbers

\begin{tabular}{lll}
\hline \hline Uchumataqu & Uru Ch'imu & Lengua X \\
\hline taqčuku 'six' & $<$ tắxsō> 'six' & $<$ tajsu> 'six' \\
sanqu 'nine' & $<$ sắnko> 'nine' & $<$ chanaku> 'eight' \\
\hline
\end{tabular}

Data from Posnansky (1938:53), Camacho (1950:252), Muysken (2005), and Hannß (2014b:197). In the context of Uru Ch'imu taxso: 'six' and related forms, there is some similarity with Quechua suqta 'six' (Willem Adelaar, personal communication, September 2015). As to the fact that in some cases, the numeric values in Lengua $X$ and Uru do not seem to match, similar observations have been made in other contexts as well (e.g., Urban 2015), and non-matching numerals are also widely attested even within Lengua X.

In some cases, there seem to be parallels in Uchumataqu, as pointed out by Adelaar (2004:375), specifically with regard to Uchumataqu 'six' and 'nine', as observed by Ibarra Grasso (1982:102-3) and shown in table 4. Numbers larger than four, as illustrated in the Uru varieties of Ch'imu and Uchumataqu in table 4, are difficult to reconstruct for Proto-Uru-Chipayan since Chipaya only has numbers from 'one' to 'four' and uses Aymara words for larger values (cf. Cerrón-Palomino 2006:104). It is likewise difficult to propose a scenario by which the Lengua $X$ numbers illustrated in table 4 would have derived from Proto-Uru-Chipayan.

Despite the difficulty of establishing an origin of these words in ProtoUru-Chipayan, an element found in a few Lengua $X$ numbers above 'five', and which does seem to have an Uru-Chipayan origin, is -či or -čiči as in <olajchi> 'nine' (recorded in Chipaya), ačači 'seven, eight', and <ačíči> 'nine' (recorded in Irohito). In Uchumataqu, -č $i$ or reduplicated -čiči indicates ownership and is attached to digits in numbers above ten (Hannß 2008:208). Its Aymara counterpart, -ni, has the same function (cf. Adelaar 2004:277) and seems to be reflected in the Lengua $X$ terms <kolquini> 'seven' and <chipani> 'eight' (table 1). 
TABLE 5

Lengua X Numbers and Quechua/Aymara Lexical Items

\begin{tabular}{ll}
\hline \hline Aymara/Quechua & Lengua X \\
\hline čanaku Quechua 'youngest son' & $<$ chanaku> and related forms 'five, eight, nine' \\
wanaku 'guanaco', in Quechua also 'to repent, & wanaku 'six, seven' \\
better one's life' & ačači 'seven, eight' \\
ačači 'old man, grandfather' & $<$ kolquini> 'seven' \\
qul'qini Aymara 'rich person' & $<$ kolke> 'nine, ten' \\
qul'qi Quechua/Aymara 'money' & $<$ chipana> 'seven, eight, nine' \\
čipana 'bracelet' & $<$ olajchi> 'nine' \\
uraqači Quechua 'to cut off, lower sth.' &
\end{tabular}

Aymara and Quechua data from De Lucca (1983), Rosat Pontacti (2004).

The ending <-ku/-ko/-qu> in table 4 is found in several Ch'imu Uru numbers and in most Uchumataqu numbers above 'four'; for instance, in Uchumataqu taqč $k$ ku 'six' and Ch'imu Uru <sắnko> 'nine' (see also table I in the appendix). In Lengua $\mathrm{X}$, it is attested in wanaku 'six, seven' and <chanaku> 'eight'.

Another relevant observation regards the recurrent element $q a l^{y} q u$, attested in some Aymara numbers, which has a counterpart in Lengua $X<$ acargu $>$ and $<$ takarko $>$ (both 'six'). The Aymara element qaly $q u$ has been interpreted as a fossilized term for 'five' in paqaly $q u$ 'seven' (cf. paya 'two') and kimsaqal' $q u$ 'eight' (cf. kimsa 'three') (e.g., Middendorf 1891:37). This constituent of Aymara numbers has no parallel in Jaqaru (cf. Belleza Castro 1995). Given the recurrent character of <-ku/-ko/-qu> in Uchumataqu, Ch'imu Uru, and some Lengua $X$ terms, and bearing in mind that in Uru-Chipayan languages, numbers may have referred to pairs as counting units (3.2), the fossilized element qaly $q u$ 'five' in Aymara numbers and its counterparts in Lengua $\mathrm{X}<$ acargu $>$ and $<$ takarko $>$ might be compared with Uchumataqu $q^{h}$ alo and Ch'imu Uru <khấro > 'ten'.

Finally, as shown in table 4, Lengua $X<$ chanaku> 'eight' and related forms resemble Quechua čanaku 'youngest son'. In fact, several similar cases of Lengua X numbers above 'five' are homophonous with Quechua or Aymara terms (table 5). Since the Aymara/Quechua terms given in table 5 would be extremely unlikely sources of numerical terms (e.g., Hammarström 2010; Epps et al. 2012), a possible explanation is hobson-jobsons. ${ }^{12}$ Hobson-jobsons are substitutions of unintelligible words or expressions from foreign languages by

\footnotetext{
12 The frequent use of numbers in trade relations would be an alternative explantion-Quechua and Aymara quly qi 'money' might be a source of Lengua X kolke, as an anonymous reviewer suggests. As s/he states, a trade-based word such as 'money' might be reinterpreted as a number in a language lacking that particular term.
} 
words or expressions that do make sense to a speaker. (An example would be French m'aidez 'help me', which was reinterpreted, in English, as "mayday"; Cowan and Rakušan 1998:179-80.) Thus, the Lengua X words illustrated in table 5 might be explained as forms that were modified by speakers of Aymara or Quechua, possibly in relatively recent times, in a way that made sense in their language. The form čipana, for instance, has been recorded as the Lengua X terms for 'seven', 'eight', or 'nine' in several cases. In Quechua and Aymara, čipana means 'bracelet'. Simultaneously, the Lengua X number may contain an element derived from Uru-Chipayan $\check{c}^{h} e p$ 'three' or Mosetén $\check{c}^{h}$ ibin 'three'. ${ }^{13}$ In some instances, Spanish probably also provided hobsonjobsons; compare, for example, Uchumataqu sanqu 'nine', Spanish chaleco 'vest', Lengua $\mathrm{X}<$ chaleco $>$ 'nine' in table 2 . Virtually nothing is known about the specific contexts in which the published Lengua $X$ series were gathered, and in some cases the person recording the Lengua $\mathrm{X}$ words or an interpreter may also have been the source of these substitutions.

4. Conclusion and Discussion. This paper has examined the so-called Lengua X numbers of the south-central Andes, discussing their external relations, and showing that most of them can be traced to other languages of the area. Lengua X 'one' and 'two' seem to originate in Aymara (3.1), and the terms from 'three' to 'five' can be explained as morphologically complex forms in Mosetén (3.2). This makes Lengua X the only instance of words for numbers originating in a lowland or piedmont language (Mosetén, in this case) being used in the Andean highlands-usually, it is the other way round, as for example in Apolista (Arawakan) and Cavineña (Tacanan) (see table II in the appendix). As for Lengua X terms from 'six' to 'ten', it is impossible to draw a clear picture; some single elements can be linked to Uru-Chipayan languages, and several Lengua $\mathrm{X}$ words seem to have been modified by speakers of Aymara and Quechua, leading to hobson-jobsons (3.3).

Given these external relations, it is important to ask what the context that gave rise to this etymologically mixed numerical system might have been. The most basic words in Lengua X, namely the terms for 'one' and 'two', mayti and payti, derive from Aymara maya 'one' and paya 'two'. Thus, Lengua X series seem to mirror the situation of lowland languages such as Apolista and Cavineña where only the terms for 'one' and 'two' are native, whereas higher numbers are borrowed from highland languages. Across different languages, the terms for 'one' and 'two' have been shown to be among the forty most stable lexical items, diachronically speaking (Holman et al. 2008), and thus top the stability hierarchy. This suggests that the people who created the Lengua $\mathrm{X}$ numerical series were probably speakers of an Aymaran language. Since

\footnotetext{
${ }^{13}$ Final in in the Mosetén $\check{c}^{h} i b i n$ 'three' might be a plural marker (cf. Sakel 2004:81).
} 
the area where Lengua $X$ terms have been recorded has been populated not only by Uru-Chipayan-speaking groups but also, since AD 1100-1400 (Adelaar 2012:589), by Aymara-speaking people, the formation of Lengua X numbers probably occurred after that.

The words from 'three' to 'five' are lower in the stability hierarchy and apparently originate in Mosetén, since they can be analyzed as morphologically complex forms in this language. An equivalent of Lengua $\mathrm{X}<$ yunkati> 'four' already existed when Aymara-speaking groups came into contact with speakers of Mosetén (compare Proto-Aymaran *puši 'four'; Emlen 2017), and there was apparently no need for Aymara-speakers to borrow this term. A source from the seventeenth century (Meléndez 1682:814-18) suggests that there was contact between Aymara-speaking and neighboring Moseténspeaking groups; also, many Mosetén understood or even spoke Aymara at that time (Métraux 1942:18, 1948:487). Nonetheless, Mosetén does not seem to have undergone heavy influence from Aymara (Sakel 2004:4), nor vice versa, and the exact circumstances of Mosetén-Aymara contact in the past remain obscure, though trade may have played a role (Métraux 1942:18). Having said that, given that our earliest information on Lengua $\mathrm{X}$ numbers dates from the late nineteenth century, it cannot necessarily be synthesized with the ethnohistorical evidence from the seventeenth century.

As to the role of Uru-Chipayan languages in the context of Lengua $\mathrm{X}$ terms, Uchumataqu words can be linked with some Lengua $\mathrm{X}$ terms for 'six' and 'eight', as argued by Ibarra Grasso (1982:102-3). The same is true for numbers from Ch'imu Uru. Additionally, some endings attested in Lengua X numbers above 'five', such as final -či/-čiči and -ku/-ko/-qu, recur in words from Uchumataqu and Ch'imu Uru. In this context, it is also relevant to note that Uru-Chipayan-speaking groups had interacted with peoples from the eastern foothills (Pache et al. 2016), some of whom spoke Mosetenan languages (Créqui-Montfort and Rivet 1926; Jolkesky 2016:513). ${ }^{14}$

In sum, this paper has shown that it is difficult to trace these words which are attested sporadically in the south-central Andes to an individual, vanished language, "Lengua X." Also, there is no evidence that the series in question were ever part of a more elaborate trade jargon or pidgin that arose in a contact situation between highland and lowland populations. Instead, Lengua $\mathrm{X}$ numbers seem to be a singular epiphenomen emerging from complex intergroup relations, whereby the origin of the different forms is more easily discernible in the lower numbers than in the higher numbers. In their multivocality, and in their convoluted origin, these series appear to be unique. Tracing the characteristics and the origin of Lengua $X$ numbers, this paper

\footnotetext{
${ }^{14}$ Compare, for instance, Mosetén son ${ }^{y} i ?$ 'man', tya:ra: 'maize', ch $^{y}$ ibin 'three' (Sakel 2004) and Chipaya šson'y 'man', tara 'maize', čch ep 'three' (Cerrón-Palomino and Ballón Aguirre 2011).
} 


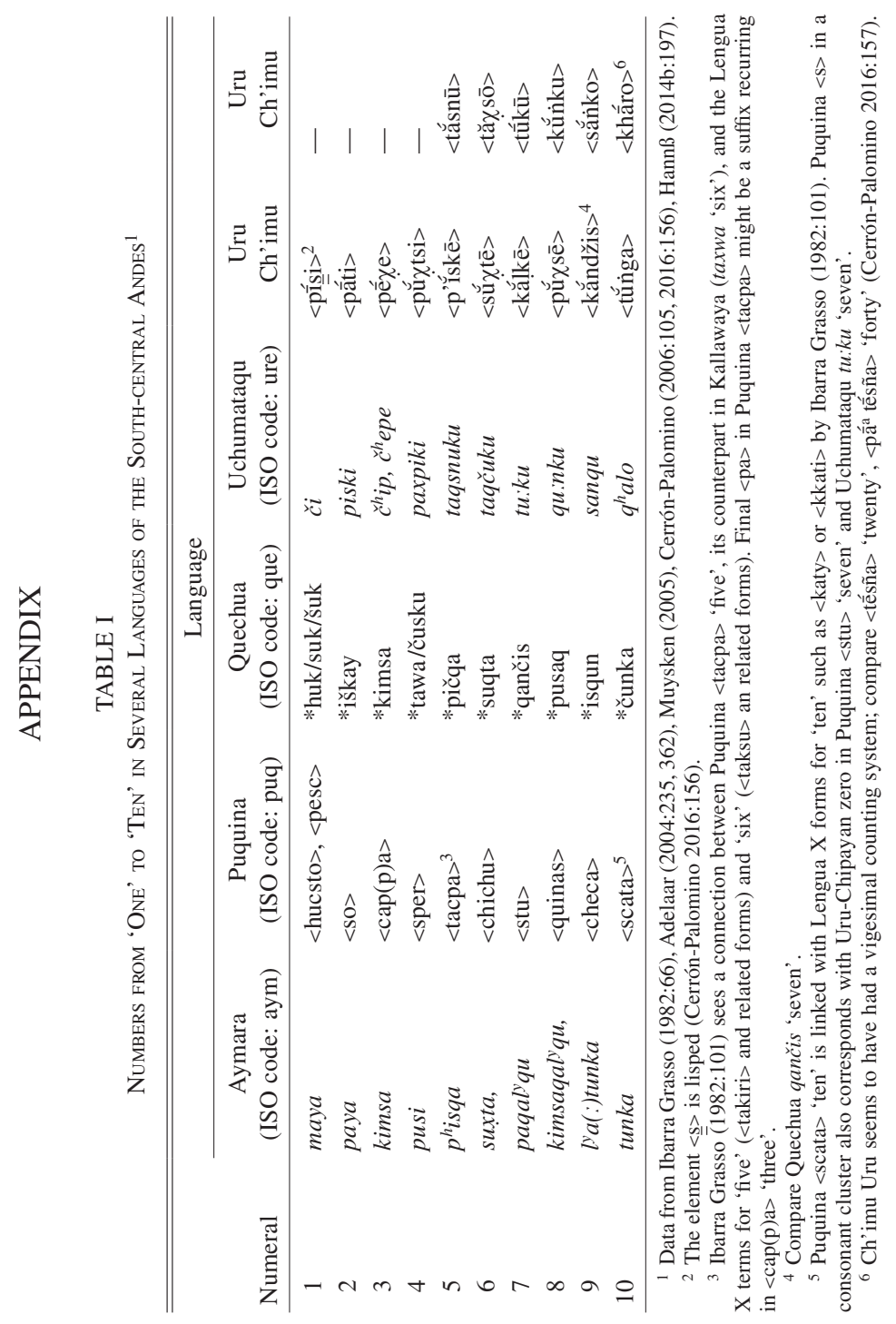




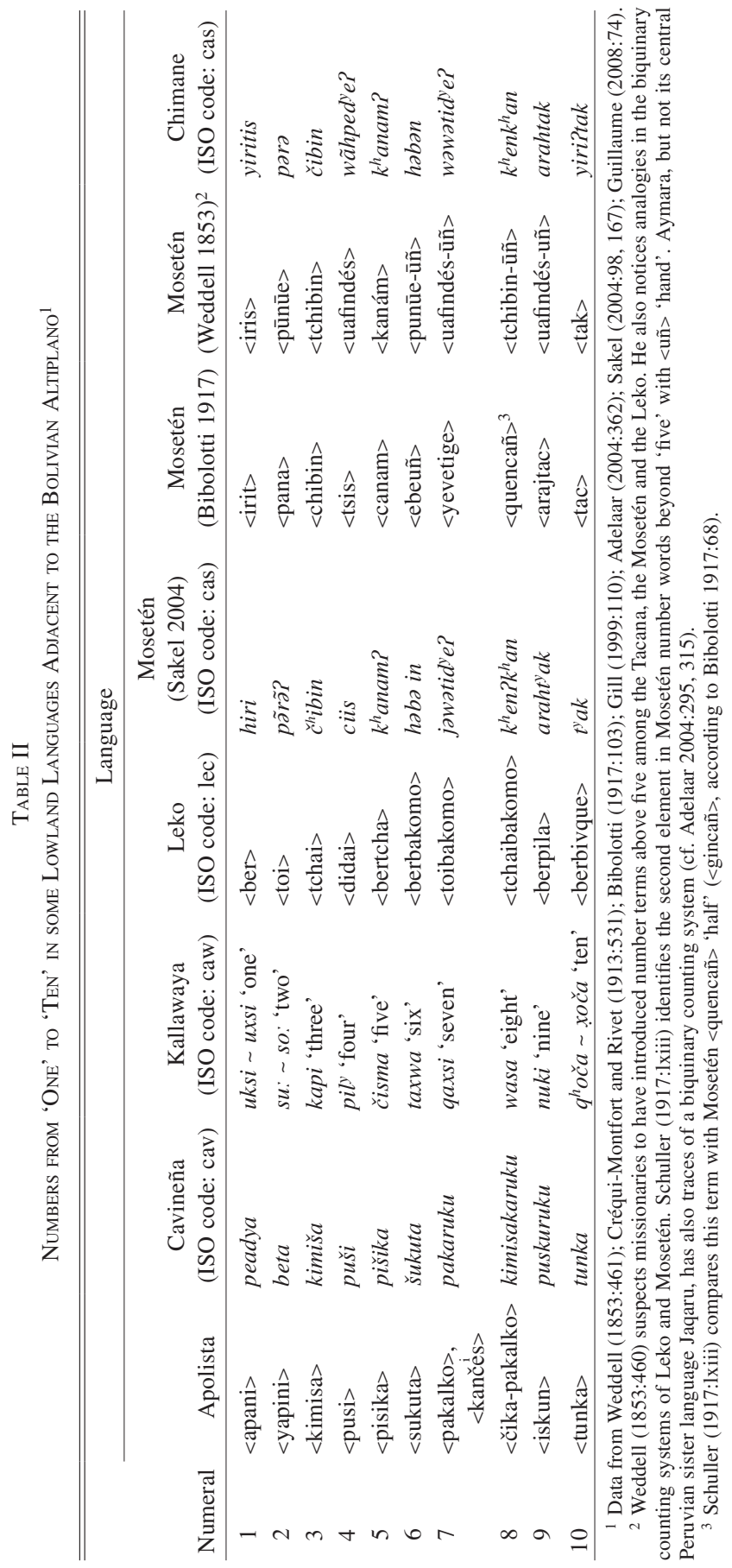


has also illustrated how a relatively minor phenomenon may ultimately turn out to reveal the echoes of a complex and dynamic linguistic past.

\section{REFERENCES}

Adelaar, Willem F. H. 2004. The Languages of the Andes, with Pieter C. Muysken. Cambridge: Cambridge University Press.

. 2012. Languages of the middle Andes in areal-typological perspective. The Indigenous Languages of South America, ed. Lyle Campbell and Verónica Grondona, 575-624. The World of Linguistics, vol. 2. Berlin: De Gruyter Mouton.

Aikhenvald, Alexandra Y. 2002 Language Contact in Amazonia. Oxford: Oxford University Press.

Belleza Castro, Nely. 1995. Vocabulario jacaru-castellano, castellano-jacaru (aimara tupino). Monumenta linguistica andina, no. 3. Cuzco: Centro de Estudios Regionales Andinos Bartolomé de Las Casas.

Bender, Andrea, And Sieghard Beller. 2014. Mangarevan invention of binary steps for easier calculation. Proceedings of the National Academy of Sciences 111 (4):1322-27.

Bertonio, Ludovico. 2006 [1612]. Vocabulario de la lengua aymara. Arequipa: El Lector.

Bibolotti, Benigno. 1917. Moseteno Vocabulary and Treatises, from an unpublished manuscript in possession of Northwestern University Library, with an introduction by Rudolph Schuller. Evanston and Chicago: Northwestern University.

Bolaños, Katherine. 2016. A Grammar of Kakua. Utrecht: Netherlands Graduate School of Linguistics (LOT).

BouysSe-CASSAgne, ThérÈSe. 1975. Pertenencia étnica, status económico y lenguas en Charcas a fines del siglo XVI. Tasa de la visita general de Francisco de Toledo, ed. Noble David Cook, 312-28. Lima: Universidad Nacional Mayor de San Marcos.

Camacho, Joel V. 1950. Orígenes de Bolivia. Revista Jurídica de la Facultad de Derecho XIII (53):150-244. Cochabamba: Universidad Mayor de San Simón.

Cerrón-Palomino, Rodolfo. 2000. Lingüística aimara. Cuzco: Centro de Estudios Regionales Andinos Bartolomé de Las Casas.

. 2006. El chipaya o la lengua de los hombres del agua. Lima: Fondo Editorial de la Pontificia Universidad Católica del Perú.

. 2016. El uro de la bahía de Puno, with Jaime Barrientos Quispe and Sergio Cangahuala Castro. Publicaciones del Instituto Riva-Agüero, no. 322. Lima: Pontificia Universidad Católica del Perú, Instituto Riva-Agüero.

Cerrón-Palomino, Rodolfo, and Enrique Ballón Aguirre. 2011. Chipaya: Léxico y etnotaxonomía. Lima: Fondo Editorial de la Pontificia Universidad Católica del Perú and Centre for Language Studies, Radboud Universiteit Nijmegen.

Cowan, William, and Jaromira Rakušan. 1998. Source Book for Linguistics. Amsterdam and Philadelphia: John Benjamins.

Créqui-Montfort, Georges de, and Paul Rivet. 1913. Linguistique bolivienne. La langue lapaču ou apolista. Zeitschrift für Ethnologie 45 (3):512-31.

1926. La langue uru ou pukina (suite). Journal de la Société des Américanistes 18 (1):111-39.

De Lucca, Manuel. 1983. Diccionario aymara-castellano, castellano-aymara. La Paz: Comisión de Alfabetización y Literatura en Aymara (CALA).

Emlen, Nicholas Q. 2017. Perspectives on the Quechua-Aymara contact relationship and the lexicon and phonology of Pre-Proto-Aymara. IJAL 83 (2):307-40.

EpPs, PAtienCE. 2006. Growing a numeral system: The historical development of numerals in an Amazonian language family. Diachronica 23 (2):259-88. 
Epps, Patience, Claire Bowern, Cynthia A. Hansen, Jane H. Hill, and Jason Zentz. 2012. On numeral complexity in hunter-gatherer languages. Linguistic Typology 16 (1):41-109.

Gill, WAYne. 1999. A Pedagogical Grammar of the Chimane (Tsimane') Language. New Tribes Mission, Bolivia.

Grimes, Barbara F. (ed.) 2000. Ethnologue, vol. 2. Dallas: SIL International.

Guerra GutiérRez, Alberto. 1984. Oruro: Realidad socio-cultural. Oruro: Cordeor.

Guillaume, Antoine. 2008. A Grammar of Cavineña. Mouton Grammar Library, no. 44. Berlin: Mouton de Gruyter.

Guirardello, RaQuel. 1999. A reference grammar of Trumai. Ph.D. dissertation, Rice University.

HAMMARSTRÖM, HARALD. 2010. Rarities in numeral systems. Rethinking universals: How rarities affect linguistic theory, ed. Jan Wohlgemuth and Michael Cysouw, 11-59. Berlin: De Gruyter Mouton.

Hannss, Katja. 2008. Uchumataqu: The Lost Language of the Urus of Bolivia. A Grammatical Description of the Language as Documented between 1894 and 1952. CNWS Publications, vol. 158, Indigenous Languages of Latin America (ILLA), no. 7. Leiden.

. 2014a. Reduplication strategies in Kallawaya. Word Formation in South American Languages, ed. Swintha Danielsen, Katja Hannß, and Fernando Zúñiga, 163-80. Amsterdam and Philadelphia: John Benjamins.

. 2014b. The Uru of Ch'imu: An investigation of Walter Lehmann's material. Sprachtypologie und Universalienforschung 67 (2):175-211.

Holman, Eric W., Søren Wichmann, Cecil H. Brown, Viveka Velupillai, André Müller, and Diк BAKKER. 2008. Explorations in automated language classification. Folia Linguistica 42 (2):331-54.

Ibarra Grasso, Dick Edgar. 1964. Lenguas indígenas de Bolivia. Cochabamba: Universidad Mayor de San Simón, Museo Arqueológico.

. 1982. Lenguas indígenas de Bolivia. La Paz: Librería Editorial Juventud.

Ifrah, Georges. 1994. Histoire universelle des chiffres, vol. 1. Paris: Robert Laffont.

JolKeSKY, MARCELO. 2016. Estudo arqueo-ecolinguístico das terras tropicais Sul-Americanas. Ph.D. dissertation, Universidade de Brasília.

Lehmann, Walter. 1920. Zentral-Amerika. 1. Teil. Die Sprachen Zentral-Amerikas. Berlin: Dietrich Reimer (Ernst Vohsen).

Martins, Silvana, and Valteir Martins. 1999. Makú. The Amazonian languages, ed. Robert M. W. Dixon and Alexandra Y. Aikhenvald, 251-67. Cambridge: Cambridge University Press. Meléndez, Ivan. 1682. Tesoros verdaderos de las Indias. vol. 3. Rome: Nicolás Angel Tinassio. Métraux, Alfred. 1942. The Native Tribes of Eastern Bolivia and Western Matto Grosso. Smithsonian Institution Bureau of American Ethnology, Bulletin 134. Washington, DC: Government Printing Office.

. 1948. Tribes of the eastern slopes of the Bolivian Andes. Handbook of South American Indians, ed. Julian H. Steward, vol. 3, 465-506. Washington, DC: Government Printing Office. MiddendoRf, ERnst W. 1891. Die Aimarà-Sprache. Mit einer Einleitung über die frühere Verbreitung der diese Sprache redenden Rasse und ihr Verhältnis zu den Inkas. Die einheimischen Sprachen Perus, vol. 5. Leipzig: F. A. Brockhaus.

Miranda Mamani, Lucas, Daniel Moricio Choque, and Saturnina Alvarez de Moricio. 1992. Memorias de un olvido: Testimonios de vida uru-muratos, ed. Rossana Barragán. La Paz: Fundación para la Investigación Antropológica y el Etnodesarrollo 'Antropólogos del Surandino' (ASUR) and Editorial Hisbol.

Montaño Aragón, Mario. 1972. Los capillu: Descubrimiento de un nuevo grupo humano en Bolivia. Pumapunku 4:64-70.

Montoya, Antonio Ruiz De. 1639. Tesoro de la lengua guaraní. Compuesto por el Padre Antonio Ruiz, de la Companía de Jesús. Madrid: Juan Sánchez.

Muysken, Pieter C. 2005. El idioma uchumataqu. Irohito: Distrito Nacionalidad Indígena Urus de Irohito. 
2010. The demise and attempted revival of Uchumataqu (Uru): Values and actors. New Perspectives on Endangered Languages: Bridging Gaps between Sociolinguistics, Documentation and Language Revitalization, ed. José Antonio Flores Farfán and Fernando Ramallo, 93-118. Amsterdam and Philadelphia: John Benjamins.

Niño Vargas, Juan CAmilo. 2009. Sistema de clases y principio de paridad: observaciones lingüísticas y etnográficas sobre el sistema de numeración ette (chimila). Estudios de Lingüística Chibcha 28:75-108.

Opie, Iona, And Peter Opie. 1997. The Oxford Dictionary of Nursery Rhymes. Oxford: Oxford University Press.

Pache, Matthias, Søren Wichmann, and Mikhail Zhivlov. 2016. Words for 'dog' as a diagnostic of language contact in the Americas. Language Contact and Change in the Americas: Studies in honor of Marianne Mithun, ed. Andrea Berez-Kroeker, Diane Hintz, and Carmen Jany, 385-409. Amsterdam and Philadelphia: John Benjamins.

Pica, Pierre, Cathy Lemer, Véronique Izard, and Stanislas Dehaene. 2004. Exact and approximate arithmetic in an Amazonian indigene group. Science 306 (5695):499-503.

Posnansky, Arthur. 1938. Antropología y sociología de las razas interandinas y de las regiones adyacentes. La Paz: Editorial Renacimiento.

Pozzobon, Jorge. 1997. Langue, société et numération chez les Indiens maku (Haut Rio Negro, Brésil). Journal de la Société des Américanistes 83:159-72.

Rosat Pontacti, Adalberto A. 2004. Diccionario enciclopédico quechua-castellano del mundo andino. Cochabamba: Editorial Verbo Divino.

Sakel, Jeanette. 2004. A Grammar of Mosetén. Mouton Grammar Library, no. 33. Berlin: Mouton de Gruyter.

Schleicher, Charles Owen. 1998. Comparative and Internal Reconstruction of the Tupi-Guarani Language Family. Ph.D. dissertation, University of Wisconsin.

Schuller, Rudolph. 1917. Introduction. Moseteno Vocabulary and Treatises, by Benigno Bibolotti, xi-cxiii. Evanston and Chicago: Northwestern University Press.

Schumacher, Achim, Nathalie Böcker, and Francisca Condori Mollo. 2009. Chholo. Lenguas de Bolivia, vol. 1: Ámbito andino, ed. Mily Crevels and Pieter Muysken, 117-23. La Paz: Ediciones Plural.

Steinen, Karl vON DEN. 1894. Unter den Naturvölkern Zentral-Brasiliens. Reiseschilderungen und Ergebnisse der zweiten Schingú-Expedition 1887-1888. Berlin: Geographische Verlagsbuchhandlung von Dietrich Reimer.

Urban, Matthias. 2015. Notas sobre el sistema de numeración de las lenguas timote-cuicas. Boletín Antropológico 33 (90):53-69.

Vellard, Jehan A. 1949. Contribution à l'étude des Indiens uru ou kot'suñs. Travaux de l'Institut Français d'Études Andines 1:145-209.

1954. Dieux et parias des Andes: Les ourous, ceux qui ne veulent pas être des hommes. Paris: Editions Emile-Paul.

. 1967. Contribución al estudio de la lengua uru. Buenos Aires: Universidad de Buenos Aires, Facultad de Filosofía y Letras, Centro de Estudios Lingüísticos.

Wachtel, Nathan. 1978. Hommes d'eau: le problème uru (XVI ${ }^{\mathrm{e}}-\mathrm{XVII} \mathrm{I}^{\mathrm{e}}$ siècle). Annales. Histoire, Sciences Sociales 33 (5/6):1126-59.

Weddell, Hugh Algernon. 1853. Voyage dans le nord de la Bolivie et dans les parties voisines du Pérou ou, Visite au district aurifère de Tipuani. Paris: P. Bertrand and London: H. Baillière.

Wojtylak, Katarzyna I. 2015. Heterogeneous Number Words in Murui (Witoto, Northwest Amazonia). Friday Afternoon Lecture, Leiden University, June 12.

Wrigley, Gladys M. 1917. The Traveling Doctors of the Andes: The Callahuayas of Bolivia. Geographical Review 4 (3):183-96. 